\title{
KESIAPAN ASPEK SPASIAL PADA PENGEMBANGAN KAWASAN PARIWISATA BERBASIS INDUSTRI KREATIF KERAJINAN SANGKAR BURUNG DI KELURAHAN MOJOSONGO, KOTA SURAKARTA
}

\author{
Dewa Putu Aris Sadana', Nur Miladan'1, Hakimatul Mukaromah'1 \\ 1Program Studi Perencanaan Wilayah dan Kota Fakultas Teknik Universitas Sebelas Maret Surakarta
}

\begin{abstract}
Abstrak
Kelurahan Mojosongo, Kecamatan Jebres, Kota Surakarta, memiliki potensi industri kerajinan sangkar burung berdasarkan RTRW Kota Surakarta tahun 2011-2031 dan diarahkan sebagai pengembangan kawasan pariwisata berbasis industri kerajinan sangkar burung oleh RIPKA Kota Surakarta. Artikel ini membahas tentang kesiapan aspek spasial pada pengembangan kawasan di wilayah penelitian. Komponen dari kesiapan aspek spasial pada pengembangan kawasan meliputi infrastruktur penunjang, akaksesibilitas, ketersediaan lahan, dan pola persebaran industri kerajinan sangkar burung. Penelitian pada artikel ini dilakukan dengan teknik pengumpulan data berupa kuisioner, observasi lapangan, survei data sekunder, dan wawancara. Adapun teknik analisis pada penelitian ini, yaitu AHP dan skoring. Pada wilayah penelitian infrastruktur penunjang dibagi menjadi sarana penunjang dan prasarana penunjang. Sarana penunjang pada kawasan berupa showroom tidak tersedia pada kawasan. Prasarana pada kawasan meliputi prasarana persampahan, air bersih, listrik, dan telekomunikasi sudah memadai. Selanjutnya, aksesibilitas kawasan sudah siap untuk menunjang mobilisasi bagi pengunjung, karena sudah tersedianya akses jaringan jalan yang baik pada kawasan dan sudah tersedia rute angkutan umum yang melalui kawasan. Ketersediaan lahan dilihat dari ketersediaan lahan untuk showroom dan prasarana persampahan sudah tersedia, namun ketersediaan lahan untuk showroom masih kurang dibandingkan kebutuhan lahannya. Terakhir, pola persebaran industri kerajinan sangkar burung pada wilayah penelitian memiliki pola persebaran klaster, sehingga dapat menunjang terwujudnya lingkungan kreatif dan efisiensi dalam pengelolaan kawasannya. Jadi, berdasarkan hal-hal di atas, maka kesiapan aspek spasial pada pengembangan kawasan pariwisata berbasis industri kerajinan sangkar burung di Kelurahan Mojosongo masuk kedalam kategori tingkat kesiapan tinggi.
\end{abstract}

Kata kunci: Kesiapan; Aspek Spasial, Pengembangan Kawasan; Pariwisata; Industri Kerajinan Sangkar Burung; Industri Kreatif.

\begin{abstract}
Mojosongo, Jebres District, Surakarta City, has a bird handicraft industry potential based on RTRW Surakarta City at 20112031 and directed as tourism areas development based on the bird cage handicraft industry based on RIPKA Surakarta City. This article discusses about the readiness of spatial aspects in the development area of this research. This article was conducted by questionnaire data collection technique, field observation, secondary data survey, and interview. The analytical techniques of this article such as AHP and scoring. Components of the spatial aspect readiness on regional development include supporting infrastructure, accessibility, availability of land, and spatial dispersion patterns of the bird cage industry. In the research area the infrastructure is divided into supporting facilities and supporting infrastructure. Area supporting facilities of the showroom is not available in the reasearch area. Area suporting infrastructure includes waste system, clean water, electricity, and telecommunication. Furthermore, the accessibility of the area is good, because the availability of access road network is good in the area and already available public transportation routes through the reasearch area. The availability of land seen from the availability of land for showroom and waste system, but the availability of land for the showroom is still less than the needs of the land. Finally, the spatial dispersion pattern area of the bird cage industry in the research area has a pattern of cluster dispersion, so that it can support the realization of creative environment and efficiency in the management of the area. Thus, based on the above matters, the readiness of the spatial aspect in the tourism area development based on the bird cage industry in Mojosongo is included to high preparedness level category.
\end{abstract}

Keywords: Readiness; Spatial Aspects, Regional Development; Tourism; Bird Cage Handicraft Industry; Creative Industry. 


\section{PENDAHULUAN}

Surakarta merupakan kota yang memiliki potensi di bidang ekonomi kreatif. Menurut Rencana Induk Pembangunan Kepariwisataan (RipKa) Kota Surakarta, beberapa tahun ini muncul arahan terkait pengembangan kawasan pariwisata ke arah wilayah Surakarta bagian utara, memanfaatkan industri kreatif kerajinan sangkar burung sebagai daya tarik wisata. Selanjutnya, menurut profil ekonomi kreatif Kota Surakarta tahun 2013, sentra industri sangkar burung yang berada di Kelurahan Mojosongo, Kecamatan Jebres, mampu menciptakan produk yang kreatif dari segi desain dan bentuk. Selain itu pula pada Perda Nomor 1 Tahun 2012 tentang RTRW Kota Surakarta tahun 2011-2031, Pasal 41 ayat (2), bahwa Kelurahan Mojosongo diarahkan menjadi kawasan industri rumah tangga sangkar burung. Berdasarkan halhal di atas, pengembangan kawasan pariwisata berbasis industri rumah tangga kreatif kerajinan sangkar burung di Kelurahan Mojosongo merupakan sebuah inovasi konsep yang menggabungkan antara kawasan pariwisata dengan industri kreatif. Menurut Pendit (1999), bahwa hal-hal yag dapat menjadi daya tarik untuk suatu objek wisata yaitu natural amenities (benda-benda yang telah ada di alam), man made supply (hasil karya manusia), dan way of life (adat istiadat). Pada artikel ini, industri kerajinan sangkar burung dapat diklasifikasikan kedalam daya tarik wisata yang berasal dari hasil karya manusia. Selanjutnya, jika dilihat dari jenis industri kerajinan sangkar burung pada wilayah penelitian masuk kedalam jenis industri rumah tangga karena industrinya menyatu dengan kawasan permukiman. Selain itu, menurut Arbianto dalam Mawaddah (2013), menjelaskan mengenai kriteria industri rumah tangga mengatakan bahwa industri rumah tangga merupakan suatu kegiatan industri yang dilakukan pada rumah tangga/keluarga yang memiliki tenaga kerja tidak lebih dari 5 (lima) orang. Industri kerajinan sangkar burung pada wilayah penelitian memiliki tenaga kerja yang tidak lebih dari 5 (lima) orang. Dalam pengembangan suatu kawasan, aspek lingkungan (fisik ruang kawasan) perlu diperhatikan kesiapannya, karena aspek fisik merupakan salah satu pilar dari pembangunan pariwisata yang berkelanjutan . Dengan demikian pada artikel ini, penulis ingin mengetahui kesiapan aspek spasial (fisik ruang) pada pengembangan kawasan pariwisata berbasis industri kreatif kerajinan sangkar burung di Kelurahan Mojosongo, Kota Surakarta. Aspek spasial yang diteliti pada artikel ini, yaitu terkait pola persebaran indusri kerajinan sangkar burung, infrastruktur penunjang kawasan, aksesibilitas, dan ketersediaan lahan untuk pengembangan kawasan.

\section{KAJIAN TEORI}

Menurut Zakaria (2014), konsep pembangunan kawasan pariwisata berkelanjutan, terdiri dari tiga pilar utama yaitu aspek sosial (pengelolaan/manajemen), ekonomi (Produktivitas), dan lingkungan (fisik ruang). Artikel ini akan menjelaskan tentang kesiapan pengembangan kawasan pariwisata berbasis industri kerajinan sangkar burung pada aspek spasial (fisik ruang) kawasan, maka pada pemilihan variabel dari hasil kajian literatur artikel ini, memilih variabel yang masuk kedalam aspek spasial (fisik ruang). Aspek spasial yang dimaksud adalah hal-hal yang dapat diruangkan dan memiliki unsur fisik.

Menurut Redlener, dkk (2006), mengartikan kesiapan dalam hal rencana pengurangan risiko bencana meliputi tiga hal, yaitu (1) Ketersediaan dan kondisi sumber daya, (2) Bentuk perencanaan pencegahan bencana, dan (3) Kapasitas sumber daya manusia (wawasan atau pengetahuan) tentang pencegahan risiko bencana. Menurut Hamalik (2006), menyebutkan bahwa kesiapan merupakan suatu keadaan kapasitas sesuatu untuk tujuan tertentu. Jamis Drever dalam Slameto (2010), mengatakan bahwa kesiapan merupakan suatu ketersediaan untuk suatu hal. Menurut Slameto (2010), mengatakan bahwa kesiapan merupakan keseluruhan kondisi yang membuatnya siap untuk suatu hal. Selanjutnya kajian literatur terkait pengembangan kawasan akan dijelaskan melalui beberapa sumber. Menurut Adisasmita (2014), kawasan merupakan sebuah wilayah yang memiliki fungsi tertentu. Selanjutnya, menurut Adisasmita (2010), bahwa dalam mengembangankan suatu kawasan menjadi fungsi tertentu harus mempertimbangkan kondisi kawasan, kapabilitas kawasan, kesesuaian lahan, dan efektifitas dan efesiensi pembangunan kawasan.

Seletah mengetahui pemahaman tentang pengembangan kawasan, selanjutnya akan dijabarkan literatur tentang pariwisata. Menurut Pendit (1999), bahwa jenis-jenis daya tarik wisata terdiri dari natural amenities (benda-benda yang ada di alam), man made supply (hasil karya manusia), way of life (adat istiadat), culture (kebudayaan setempat). Berikutnya, menurut Spillane (1987), bahwa unsur-unsur pariwisata yaitu atraksi wisata, fasilitas penunjang, infrastruktur, transportasi, keramahtamahan. Selanjutnya menurut Pendit (1999), bahwa unsur-unsur pokok pariwisata yaitu politik pemerintah, perasaan ingin tahu, keramahtamahan, jarak dan waktu, atraksi wisata, akomodasi, pengangkutan, promosi, sarana perbelanjaan. Sedangkan menurut Cooper (1998), komponen pembentuk kawasan pariwisata yaitu atraksi wisata, amenities (fasilitas penunjang), aksesibilitas, dan kelembagaan pengelola wisata. 
Pada artikel ini, Industri rumah tangga kreatif kerajinan sangkar burung menjadi basis dari pengembangan kawasan pariwisata, maka berikut akan dijabarkan kajian literatur tentang industri rumah tangga kreatif kerajinan sangkar burung. Menurut Arbianto dalam Mawaddah (2013), kriteria industri rumah tangga yaitu kegiatan industri dilakukan di rumah, tenaga kerja tidak lebih dari 5 orang, dan alat yang digunakan adalah alat manual dan semi otomatis (bukan manufaktur). Selanjutnya, menurut Philipps (1990), faktor yang mempengaruhi pemilihan lokasi pengembangan industri yaitu pasar, sumber bahan baku, tenaga kerja, utilitas, transportasi, peraturan lingkungan, dan infrastruktur penunjang. Berikutnya, menurut UNCTAD dalam Pujihartati (2014), mengatakan bahwa sektor-sektor dalam industri kreatif meliputi periklanan, arsitektur, seni, kerajinan, desain, fasyen, film, software, musik, seni pertunjukan, publikasi, dan televisi/radio. Menurut Departemen Perdagangan RI (2008), bahwa pilar dari industri kreatif yaitu people (tenaga kerja kreatif), rantai produksi industri, teknologi, sumber daya, dan lembaga. Dalam hal ini, industri kerajinan sangkar burung masuk kedalam sektor industri kreaif kerajinan. Selanjutnya, Menurut UNINDO (2007), komponen utama dari industri kreatif sektor kerajinan yaitu kreativitas pengerajin, bahan baku alam, infrastruktur, teknologi, dan ktersediaan pasar. Kerajinan sangkar burung merupakan kerajinan dari hasil karya manusia yang berbahan baku utama bambu dan kayu yang memiliki ragam bentuk maupun ukir-ukiran agar menarik konsumen (Munawir, dkk: 2015).

Menurut Ardahla, dkk (2015) bahwa faktor-faktor yang mempengaruhi pengembangan kawasan pariwisata berbasis industri kreatif yaitu, (1) kebutuhan dasar industri kreatif (tenaga kerja kreatif, keahlian, modal, teknologi, kebijakan pemerintah, pelatihan, dan jaringan telekomunikasi); (2) artaksi wisata (kunjungan wisata kreatif, ekplorasi kreatif, tersedianya ruang workshop, dan partisipasi masyarakat); (3) aksesibilitas dan mobilisasi (jaringan jalan, rute transport, kondisi jalan); (4) pengembangan produk (produk baru dan kualitas produk). Selanjutnya, menurut Richards (2011) pendekatan konsep kreatif dalam sebuah pariwisata yaitu konsep "4P" meliputi, (1) manusia kreatif (pengerajin sangkar burung) (2) proses kreatif (workshop dan kegiatan kreatif lainnya) (3) produk kreatif (4) lingkungan kreatif (klaster industri kreatif). Berdasarkan hasil sintesa komponen kesiapan kawasan pengembangan pada artikel ini, maka dapat disimpulkan bahwa variabel pada artikel ini yaitu: (1) Atraksi wisata (lingkungan kreatif / klaster industri) ; (2) Infrastruktur penunjang; (3) Aksesibilitas; dan (4) Ketersediaan lahan.

\section{METODE PENELITIAN}

Pendekatan metode penelitian yang digunakan adalah kuantitatif, dimana pada proses analisis hingga penarikan kesimpulan akan menggunakan perhitungan statistik maupun angka. Berikut merupakan variabel dari artikel ini yaitu:

(1) Atraksi wisata (lingkungan kreatif)

Lingkungan kreatif dapat dilihat dari pola persebaran industri kerajinan sangkar burung. Pola persebaran Industri kreatif dapat diukur melalui analisis tetangga terdekat. Analisis Tetangga Terdekat merupakan analisis yang digunakan untuk menentukan pola sebaran suatu benda yang ditunjukan dari besarnya nilai T. Perhitungan analisis tetangga terdekat menggunakan formula sebagai berikut:

\section{Dengan ketentuan:}

$$
T=\frac{\overline{J u}}{\overline{J h}}
$$

$\mathrm{T}=$ indeks penyebaran tetangga terdekat, $\overline{J_{u}}=$ jarak rata-rata yang diukur antara satu titik dengan titik tetangganya yang terdekat, $\overline{J_{h}}=$ jarak rata-rata yang diperoleh andai kata semua titik mempunyai pola random $=\frac{1}{2 \sqrt{p}}, \mathrm{p}=\frac{\text { jumlah benda }(N)}{\text { luas areal yang diobservasi }(A)}$

Tabel 1. Hasil Perhitungan Analisis Tetangga Terdekat

\begin{tabular}{|c|l|}
\hline Rentang Nilai & \multicolumn{1}{|c|}{ Jenis Pola Penyebaran } \\
\hline $0,00-0,70$ & Pola mengelompok (clustered) \\
\hline $0,71-1,40$ & Pola acak (random) \\
\hline $1,41-2,1491$ & Pola seragam (reguler) \\
\hline
\end{tabular}

Sumber: Hugget dalam Bintarto, 1982

(2) Infrastruktur penunjang kawasan yang dapat dibagi menjadi sarana penunjang kawasan dan prasarana penunjang kawasan.

- Sarana: Tersedia showroom yaitu terdapat showroom di wilayah penelitian dan terdapat juga showroom yang difasilitasi pemerintah maupun yang dibuat secara swadaya.

- Prasarana penunjang: 
- Parasarana persampahan pada penyediaan bak sampah setiap RW dan adanya sistem pengangkutan secara berkala ke TPS/TPA.

- Tersedia dan mencukupinya air bersih yaitu dapat melayani kegiatan industri dan permukiman.

- Tersedia dan mencukupinya energi listrik yaitu dapat melayani kegiatan industri dan permukiman.

- Tersedia dan mencukupinya kebutuhan jaringan komunikasi yaitu dalam bentuk, jaringan telepon kabel, terlayani sinyal seluler, jaringan internet dan terdapat internet portable (wi-fi).

(3) Asksesibiltas dapat dilihat dari ketersediaan akses jaringan jalan yang baik dan rute moda angkutan umum yang melalui wilayah penelitian.

(4) Ketersediaan lahan (DDi) yang dilihat dari selisih antara peruntukan lahan pada arahan RDTR Kota Surakarta dan peruntukan lahan exsisting pada kawasan (SLi) yang selanjutnya dibandingkan dengan kebutuhan lahannya (DLi) (Muta'ali:2015).

Variabel operasional di atas diukur dengan teknik pengumpulan data observasi lapangan dan kuisioner. Selanjutnya, teknik analisis yang digunakan pada penelitian ini yaitu teknik analisis Analytical Hierarky Proccess (AHP) dan Skoring. Maka, teknik pengumpulan data dengan kuisioner dibagi menjadi dua yaitu kuisioner untuk pelaku usaha industri/ tenaga kerja industri dengan jumlah sampel 56 (lima puluh enam) responden dan kuisioner untuk para ahli (AHP) dengan jumlah sampel 30 (tiga puluh) ahli/pakar (saaty: 2008) yang berasal dari pemerintahan, akademisi, dan organisasi masyarakat/pelaku usaha industri kerajinan sangkar burung. Berikut merupakan tahapan dari masing-masing teknik analisis di atas:

(1) Teknik Analisis AHP

Teknik analisis AHP digunakan untuk menentukan bobot atau prioritas dari setiap variabel peneltian berdasarkan pendapat para ahli. Prioritas atau bobot dari setiap variabel penelitian akan digunakan sebagai salah satu input dari teknik analisis skoring. Pada teknik analisis ini, jawaban para ahli disintesis dan dihitung consistency ratio (CR), dapat diterima jika CR< 0,1 (saaty, 2008). Jika diterima, maka dapat dilanjutkan untuk menghitung prioritas tiap variabel.

(2) Teknik Analisis Skoring

Teknik analisis skoring digunakan untuk menarik kesimpulan dari tingkat kesiapan aspek spasial pada pengembangan kawasan penelitian ini. Berikut merupakan tahapan dari teknik analisis skoring pada artikel ini:

- Menentukan skor indikator dari masing-masing variabel yaitu, skor 1 (sangat tidak siap), skor 2 (tidak siap), skor 3 (agak siap), skor 4 (siap), dan skor 5 (sangat siap). Skor dibagi menjadi 5 (lima) kategori sesuai dengan tingkat kesiapannya.

- Menentukan skor setiap variabel dengan mencari rata-rata skor setiap variabel penelitian berdasarkan data dan analisis setiap variabel penelitian.

- Rata - rata $($ mean $)=\frac{\left.\sum \text { (Skor komponen }\right)}{\text { Jumlah komponen }}$

- Mengkalikan antara skor setiap variabel penelitian dengan bobot/prioritas dari hasil analisis AHP

- Menentukan interval kesiapan dengan rumus: Interval $=\frac{\text { Nilai maksimal-nilai minimal }}{\text { Jumlah Kelas }}=\frac{5-1}{5}=0,80$

Tabel 2. Ketentuan Skor Komponen Kesiapan Pengembangan Kawasan

\begin{tabular}{|c|c|}
\hline Skor & Keterangan \\
\hline $5,00-4,20$ & Sangat Siap \\
\hline $4,19-3,40$ & Siap \\
\hline $3,39-2,60$ & Agak Siap \\
\hline $2,59-1,80$ & Tidak Siap \\
\hline $1,79-1,00$ & Sangat Tidak Siap \\
\hline
\end{tabular}

Sumber: Peneliti, 2017

- Menentukan nilai kesiapan dari pengembangan kawasan berdasarkan kategori dari interval yang telah ditentukan.

\section{HASIL DAN PEMBAHASAN}

Berdasarkan hasil analisis data sesuai dengan metode penelitian pada pembahasan sebelumnya, maka akan dijabarkan hasil dan pembahasan artikel ini. Adapun dua hal yang akan disampaikan, yaitu pembahasan hasil dari analisis AHP, dan analisis skoring (penentuan tingkat kesiapan aspek spasial kawasan secara keseluruhan). Berikut merupakan penjabaran dari hal-hal di atas: 
(1) Prioritas/bobot setiap variabel

Berdasarkan hasil kuisioner kepada 30 pakar/ahli, maka dapat disintesa kedalam matrik perbandingan berpasangan dengan rata-rata geometri (GM). Selanjutya, diuji nilai consistency ratio (CR) dengan rumus $\mathrm{CR}=$ $\mathrm{CI} / \mathrm{RI}$ maka, $\mathrm{CR}=0,0023 / 1,45=0,0016$. Jadi, dapat disimpulkan bahwa jawaban dari para ahli adalah konsisten dan dapat diterima karena nilai $C R<0,1$. Setelah mengetahui nilai rasio konsistensi, maka matrik perbandingan berpasangan degan rata-rata geometri di atas dapat dimasukkan ke dalam software expert choice 11 untuk dicari prioritas/bobot dari masing-masing variabel. Berikut merupakan hasil dari analisis prioritas/bobot dari setiap variabel:

Tabel 3. Hasil Analisis Prioritas/Bobot setiap Variabel

\begin{tabular}{|c|c|}
\hline Variabel & Prioritas/bobot \\
\hline Lingkungan Kreatif & $27,77 \%$ \\
\hline Infrastruktur Penunjang & $25,71 \%$ \\
\hline Aksesibilitas & $25,13 \%$ \\
\hline Ketersediaan Lahan & $21,39 \%$ \\
\hline \multicolumn{2}{|c|}{ Sumber: Analisis Peneliti, 2017}
\end{tabular}

(2) Kesiapan aspek spasial pada pengembangan kawasan

Kesiapan aspek spasial akan diukur dengan teknik analisis skoring dengan mencari skor kesiapan setiap variabel. Selanjutnya, dari skor-skor kesiapan setiap variabel dikalikan dengan prioritas/bobot variabelnya, sehingga dapat dihitung skor kesiapan akhir penelitian ini. Berikut merupakan pembahasan dari kesiapan setiap variabel penelitian ini:

\section{- Lingkungan kreatif (Klaster industri)}

Semakin meklaster pola persebaran dari industri kerajinan sangkar burung di wilayah penelitian maka semakin mudah terwujudnya lingkungan kreatif pada kawasan (Richards, 2011). Dari hasil analisis pola persebaran industri kerajinan sangkar burung di wilayah penelitian maka didapatkan hasil $\mathrm{T}=0,35$ (memiliki pola persebaran mengelompok/klaster). Dengan demikian pada wilayah penelitian sangat berpotensi untuk diwujudkan lingkungan kreatif yang memanfaatkan klaster industri kreatif kerajinan sangkar burung. Hal tersebut juga dapat menjadi daya tarik wisata dari wilayah penelitian. Selain itu, dengan pola persebaran industri kerajinan yang mengelompok/klaster maka kawasan memiliki efisiensi dan efektifitas yang tinggi dalam pengelolaan/manajemen pada kawasan. Jadi, dapat disimpulkan bahwa kesiapan dari variabel lingkungan kreatif masuk kedalam katagori tingkat kesiapan sangat tinggi (sangat siap).

\section{- Infrastruktur Penunjang}

Infrastruktur penunjang pada wilayah penelitian dibagi menjadi dua sub-variabel yaitu, sarana penunjang dan prasarana penunjang. Berikut merupakan pembahasan dari masing-masing hal tersebut:

\section{o Ketersediaan Sarana penunjang (Showroom)}

Pada sub-variabel sarana penunjang, akan ditinjau dari beberapa tiga parameter yaitu, (1) tersedianya showroom di wilayah penelitian; (2) showroom disediakan untuk kepentingan bersama-sama bukan pribadi; (3) showroom yang ada merupakan fasilitasi pihak pemerintah. Parameter di atas akan diukur dengan indikator yang telah ditentukan pada bab sebelumnya. Adapun instrument survey yang digunakan yaitu kuisioner dan observasi lapangan. Berdasarkan data hasil kuisioner menunjukkan bahwa 94,64\% menjawab bahwa tidak ada showroom di wilayahnya. Selanjutnya, hanya $5,36 \%$ yang menjawab bahwa ada showroom yang telah disediakan oleh pemerintah dan digunakan untuk bersama-sama yaitu showroom dari dinas koperasi dan UKM yang terletak dibelakang kampus UNS. Dengan demikian skor rata-rata dari sub-variabel sarana penunjang sebesar 1,21. Jadi, dapat disimpulkan sub-variabel sarana penunjang pada kawasan memiliki tingkat kesiapan sangat rendah (sangat tidak siap). 


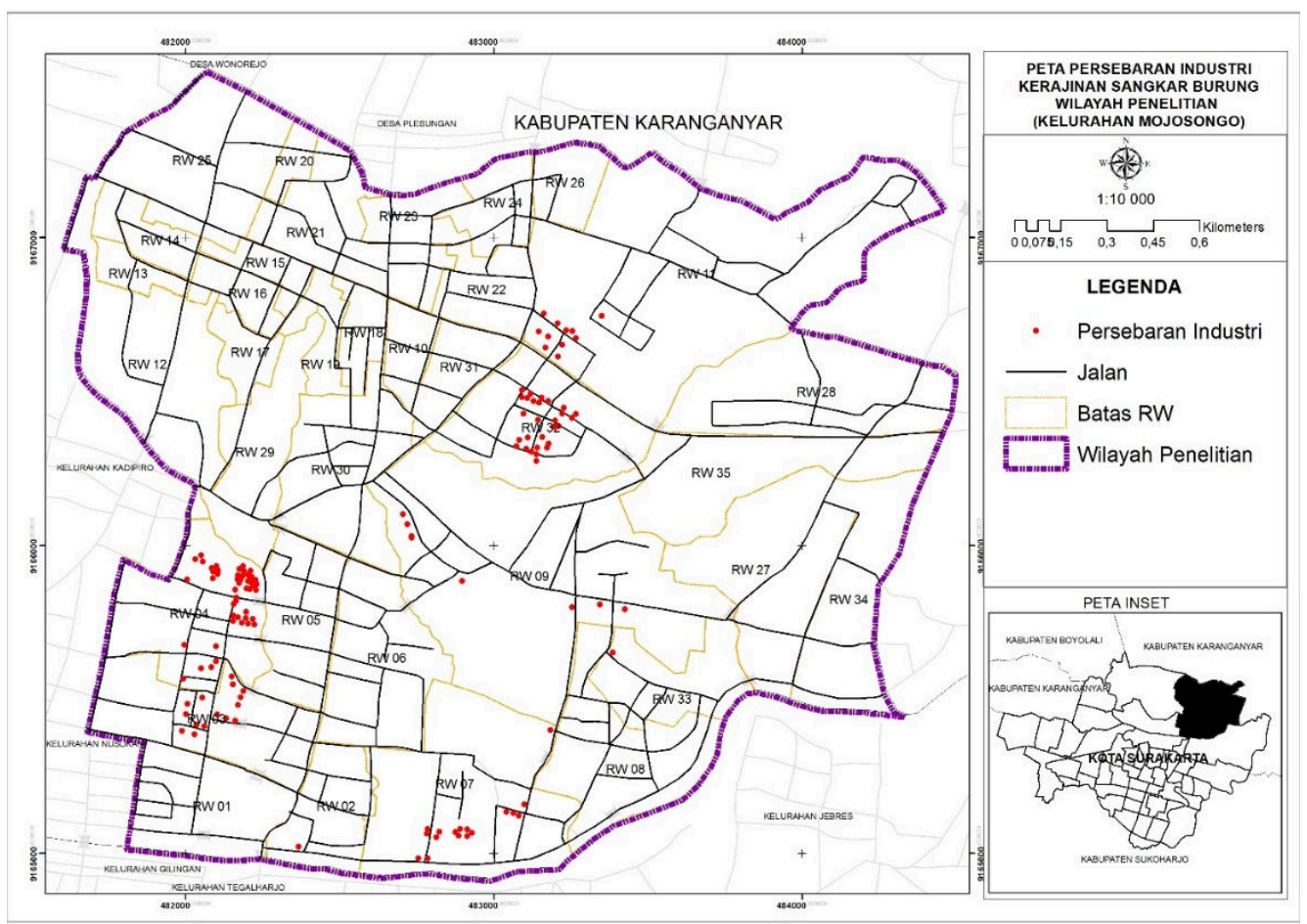

Sumber: Peneliti, 2017

Gambar 1. Peta Persebaran Industri Kerajinan Sangkar Burung di Kelurahan Mojosongo

Tabel 4. Hasil Perhitungan Pola Persebaran Industri Kerajinan Sangkar Burung di Kelurahan Mojosongo

\begin{tabular}{|c|c|c|c|}
\hline Indikator & Skor Indikator & Hasil Penelitian & Skor \\
\hline Pola penyebaran industri reguler $(1,41->2,1491)$ & 1 & \multirow{5}{*}{$\begin{array}{l}T=0,35 \rightarrow \text { maka dapat } \\
\text { disimpulkan persebaran industri } \\
\text { kerajinan sangkar burung di wilayah } \\
\text { penelitian (Kelurahan Mojosongo) } \\
\text { memiliki pola persebaran } \\
\text { mengelompok (klaster) }\end{array}$} & \multirow{5}{*}{5,00} \\
\hline Pola penyebaran industri reguler $(1,41-2,1491)$ & 2 & & \\
\hline Pola penyebaran industri random $(0,71-1,40)$ & 3 & & \\
\hline Pola penyebaran industri clustered 0.70 & 4 & & \\
\hline Pola penyebaran industri clustered $(0,00-<0.70)$ & 5 & & \\
\hline
\end{tabular}

Sumber: Analisis Peneliti, 2017

- Prasarana penunjang

- Ketersediaan dan kapasitas prasarana persampahan

Parameter pada prasarana persampahan, yaitu (1) ketersediaan sistem pengangkutan sampah; (2) sampah/limbah sisa kerajinan harus dibuang ke tempat sampah/bak sampah; (3) ketersediaan bak sampah tiap RW dengan ukuran minimal 15m²; (4) ketersediaan dan kondisi TPS atau TPA; (5) jarak TPS atau TPA ke kawasan industri kerajinan sangkar burung maksimal $1 \mathrm{~km}$ (Permen PU RI No.03/PRT/M/2013 dan SNI 03-1733-2004 tentang Tata Cara perencanaan lingkungan perumahan di perkotaan). Berdasarkan dari data dan analisis pada parameter prasarana persampahan di atas, makan dapat kita sintesis untuk mendapatkan skor dari parameter ini dengan membandingkannya dengan ketentuan skor indikator yang ada. Berdasarkan hal di atas dapat disimpukan bahwa tingkat kesiapan prasarana persampahan pada wilayah penelitian masuk kedalam kategori tingkat kesiapan sedang (agak siap). Pengembangan prasarana persampahan pada wilayah penelitian masih memerlukan cadangan lahan untuk dialokasikan sebagai peruntukan prasarana persampahan. Sehingga, perlu diketahui terlebih dahulu ketersediaan lahan dari wilayah penelitian. 
Tabel 5. Hasil Penelitian Tentang Prasarana Persampahan

\begin{tabular}{|c|c|c|c|}
\hline \multirow{2}{*}{ Parameter } & \multicolumn{2}{|c|}{ Hasil Penelitian } & \multirow{2}{*}{ Skor } \\
\hline & Memenuhi & Tidak memenuhi & \\
\hline Tersedianya bak 10-15 meter kubik di setiap RW & & $\mathrm{v}$ & \multirow{5}{*}{3} \\
\hline Sampah dibuang ketempat sampah & & $\mathrm{V}$ & \\
\hline $\begin{array}{l}\text { Tersedianya sistem pengakutan sampah secara } \\
\text { berkala }\end{array}$ & v & & \\
\hline $\begin{array}{l}\text { Tersedianya TPS dengan luas minimal } 200 \mathrm{~m}^{2} \text { atau } \\
\text { TPA }\end{array}$ & V & & \\
\hline $\begin{array}{l}\text { Jarak TPS/TPAmaksimal } 1 \text { km dari kawasan } \\
\text { industri kerajinan }\end{array}$ & v & & \\
\hline
\end{tabular}

Sumber: Analisis Peneliti, 2017

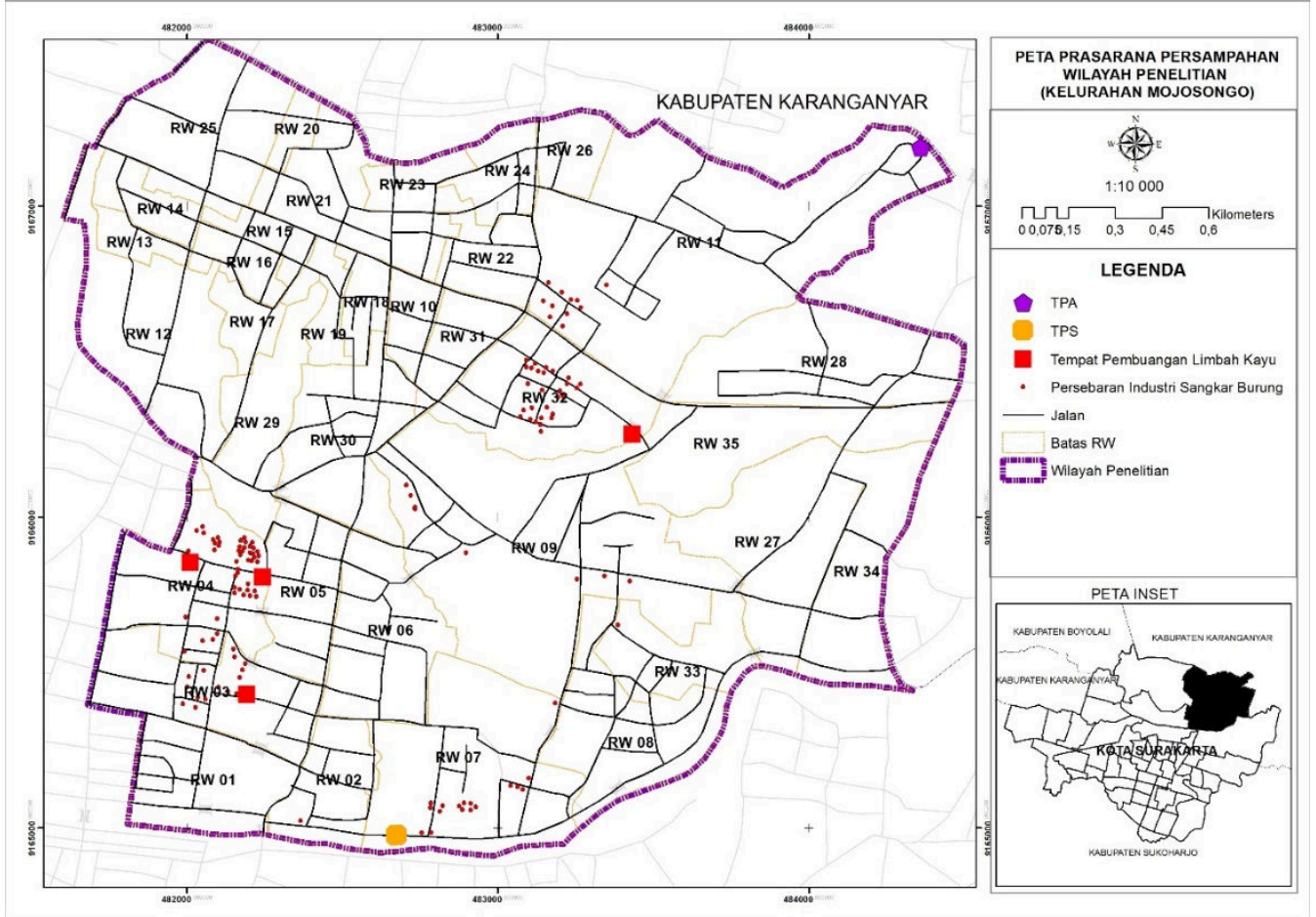

Sumber: Peneliti, 2017

Gambar 2. Peta Prasarana Persampahan di Kelurahan Mojosongo

- Ketersediaan dan kapasitas prasarana air bersih

Parameter prasarana air bersih adalah tersedianya kebutuhan air bersih bagi pelaku usaha kerajinan sangkar burung di Kelurahan Mojosongo. Prasarana air bersih digunakan untuk kebutuhan panunjang kegiatan industri kerajinan sangkar burung. Industri kerajinan sangkar burung termasuk kedalam jenis industri kecil atau industri rumah tangga. Karena jumlah tenaga kerjanya tidak lebih dari 5 orang dan kawasan industrinya menyatu dengan permukiman (Kuncoro dalam Mawaddah, 2003). Maka dari itu kebutuhan air bersih sangat diperlukan pada industri yang memiliki jenis industri rumah tangga ini. Air bersih digunakan untuk proses pelengkungan bambu dan tahap finishing. Pada wilayah penelitian prasarana air bersih mayoritas menggunakan PDAM dan sudah mampu mencukupi $\geq 30$ liter/hari untuk keperluan industri rumah tangga kerajinan sangkar burung di Kelurahan Mojosongo (SNI 03-1733-2004). Jaringan PDAM sudah sampai ke masing-masing rumah tangga di wilayah penelitian termasuk industri rumah tangga. Dengan demikian dapat disimpulkan bahwa tingkat kesiapan dari prasarana air bersih pada wilayah penelitian masuk kedalam kategori kesiapan sangat tinggi (sangat siap) dengan skor ratarata sebesar 4,92.

- Ketersediaan dan kapasitas prasarana listrik

Parameter prasarana listrik adalah tersedianya kebutuhan listrik bagi pelaku usaha kerajinan sangkar burung di Kelurahan Mojosongo. Prasarana listrik pada penelitian ini dapat menunjang kegiatan produksi 
industri kerajinan sangkar burung pada kawasan. Listrik sangat dibutuhkan untuk memenuhi kebutuhan penggunaan alat-alat produksi berteknologi yang membutuhkan tenaga listrik sebagai pembangkitnya seperti bor elektrik, pelengkung bambu, pemotong elektrik, penghalus elektrik, pengcatan semprot dan alat elektrik lainnya (Munawir, dkk, 2015). Pada wilayah penelitian prasarana listrik mayoritas pelaku usaha kerajinan sangkar burung menggunakan PLN dengan besaran daya rata-rata 450-900 VA di setiap industri kerajinan sangkar burung. Berdasarkan SNI 03-1733-2004 terkait prasarana permukiman, menunjukkan bahwa dengan kondisi tersebut maka kebutuhan listrik pada wilayah penelitian sudah mencukupi. Dengan demikian dapat disimpulkan bahwa tingkat kesiapan prasarana listrik pada wilayah penelitian masuk kedalam kategori tingkat kesiapan tinggi (siap) dengan skor rata-rata sebesar 4,11.

\section{- Ketersediaan dan kapasitas prasarana telekomunikasi}

Parameter prasarana komunikasi adalah tersedianya kebutuhan jaringan komunikasi bagi pelaku usaha kerajinan sangkar burung di Kelurahan Mojosongo. Parameter ini diukur dengan indikator yang telah ditetukan. Prasarana komunikasi pada artikel ini diguakan untuk menunjang kegiatan produksi maupun pemasaran dari industri kerajinan sangkar burung. Prasarana komunikasi ini berupa saluran telekomunikasi yang dimiliki oleh pelaku usaha industri kerajinan sangkar burung di wilayah penelitian adalah saluran telepon rumah. Dengan adanya prasarana komunikasi yang memadai maka segala sesuatu dapat diakses dengan cepat tanpa berpindah tempat. Pada wilayah penelitian mayoritas pelaku usaha industri kerajinan sangkar burung hanya memiliki satu saluran telekomunikasi yaitu hanphone. Hal ini masih tergolong kurang, karena pada SNI 03-1733-2004, mengatakan bahwa minimal setiap rumah tangga memiliki 1-2 saluran telekomunikasi. Maka dari itu dapat disimpulkan tingkat kesiapan prasarana komunikasi pada wilayah penelitian masuk kedalam kategori tingkat kesiapan sedang (agak siap) dengan skor rata-rata sebesar 2,93. Diharapkan pemerintah dapat meningkatkan prasarana komunikasi pada wilayah penelitian seperti saluran telepon rumah agar dapat memenuhi kebutuhan komunikasi dalam menunjang pengembangan kawasan pariwisata berbasis industri kerajinan sangkar burung di Kelurahan Mojosongo. Prasarana telekomunikasi ini dapat menunjang pemasaran dan prosmosi produk kerajinan sangkar burung.

Tabel 6. Hasil Kuisioner Tentang Prasarana Kawasan

\begin{tabular}{|c|c|c|}
\hline \multicolumn{3}{|l|}{ Sarana Showroom } \\
\hline Indikator & Persentase & Skor \\
\hline Tidak tersedia showroom & $95 \%$ & \\
\hline $\begin{array}{l}\text { Tersedia dan memenuhi ke } 2 \text { (dua) kriteria lainnya pada parameter dan ada } \\
\text { disetiap showroom di wilayah penelitian }\end{array}$ & $5 \%$ & 1,21 \\
\hline \multicolumn{3}{|l|}{ Prasarana Air Bersih } \\
\hline Bukan PDAM dengan mencukupi kebutuhan air bersih 30 liter/hari & $4 \%$ & \multirow[b]{2}{*}{4,92} \\
\hline $\begin{array}{l}\text { PDAM dan jaringan sampai dengan sambungan rumah dengan mencukupi } \\
\text { kebutuhan }>30 \text { liter/hari }\end{array}$ & $96 \%$ & \\
\hline \multicolumn{3}{|l|}{ Prasarana Listrik } \\
\hline Setiap unit rumah tangga dilayani PLN dengan daya listrik 450 VA & $11 \%$ & \multirow{3}{*}{4,11} \\
\hline setiap unit rumah tangga dilayani PLN dengan daya listrik 450-900 VA & $68 \%$ & \\
\hline setiap unit rumah tangga dilayani PLN dengan daya listrik >900 VA & $21 \%$ & \\
\hline \multicolumn{3}{|l|}{ Prasarana Telekomunikasi } \\
\hline Belum tersedia, namun akan diadakan & $7 \%$ & \multirow{2}{*}{2,93} \\
\hline Memiliki 1 sambungan/rumah & $93 \%$ & \\
\hline
\end{tabular}

Sumber: Analisis Peneliti, 2017

\section{- Aksesibilitas}

Asksesibilitas pada artikel ini dilihat dari dua parameter yaitu akses jaringan jalan dan rute moda transportasi. Berikut merupakan pembahasan terkait kesiapan dari masing-masing komponen terhadap pengembangan kawasan pariwisata berbasis industri kerajinan sangkar burung di Kelurahan Mojosongo. oKetersediaan dan kondisi akses jaringan jalan

Ketersediaan akses jaringan jalan pada artikel ini dilihat dari kondisi dan kapasitas jaringan jalan yang ada pada wilayah penelitian. Dengan adanya akses jaringan jalan yang baik akan memudahkan 
pengunjung untuk mengakses destinasi wisata dan bermobilisasi pada wilayah penelitian (Cooper dalam Adiati, 2014). Ketersediaan dan kecukupan akses jaringan jalan dapat diukur dengan adanya akses jalan yang memiliki kriteria sesuai dengan jenis jalannya. Sintesa skor untuk parameter ini dapat dilakukan dengan membandingkannya dengan indikator yang telah di tentukan. Berikut merupakan tabel sintesa skor ketersediaan akses jaringan jalan.

Tabel 7. Skor Ketersediaan Akses Jaringan Jalan

\begin{tabular}{|c|c|c|c|}
\hline Indikator & $\begin{array}{c}\text { Skor } \\
\text { Indikator }\end{array}$ & Hasil Penelitian & $\begin{array}{c}\text { Sko } \\
r\end{array}$ \\
\hline $\begin{array}{l}\text { - Jalan Arteri dengan lebar }<7 \text { meter dan kondisi berlubang atau } \\
\text { bergelombang (bukan aspal) } \\
\text { - Jalan Kolektor dengan lebar <6 meter dan kondisi berlubang atau } \\
\text { bergelombang (aspal) } \\
\text { - Jalan lokal: lebar jalan }<2 \text { m (bukan aspal) kondisi tidak berlubang } \\
\text { - Jalan lingkungan: }<1 \mathrm{~m} \text { (bukan aspal) kondisi buruk }\end{array}$ & 1 & \multirow{5}{*}{$\begin{array}{l}\text { - Jalan Arteri, lebar } \\
16 \mathrm{~m}, \text { kondisi } \\
\text { bergelombang, } \\
\text { perkerasan aspal } \\
\text { - Jalan Kolektor, } \\
\text { lebar 6-8m, } \\
\text { kondisi baik, } \\
\text { perkerasan aspal } \\
\text { - Jalan Lokal, lebar } \\
\text { 4-10m, kondisi } \\
\text { baik, perkerasan } \\
\text { aspal } \\
\text { - Jalan Lingkungan, } \\
\text { lebar 2-4 meter, } \\
\text { kondisi baik, } \\
\text { perkerasan aspal }\end{array}$} & \multirow{5}{*}{5,00} \\
\hline $\begin{array}{l}\text { - Jalan Arteri dengan lebar }<7 \text { meter dan kondisi baik (aspal) } \\
\text { - Jalan Kolektor dengan lebar }<6 \text { meter dan kondisi baik (aspal) } \\
\text { - Jalan lokal: lebar jalan } 2 \mathrm{~m}>\mathrm{x}<5 \mathrm{~m} \text { (bukan aspal) kondisi tidak } \\
\text { berlubang } \\
\text { - Jalan lingkungan: } 1 \mathrm{~m}>\mathrm{x}<2 \mathrm{~m} \text { (bukan aspal) kondisi tidak berlubang }\end{array}$ & 2 & & \\
\hline $\begin{array}{l}\text { - Jalan Arteri dengan lebar }=7 \text { meter dan kondisi baik (aspal) } \\
\text { - Jalan Kolektor dengan lebar }=6 \text { meter dan kondisi baik (aspal) } \\
\text { - Jalan lokal: lebar jalan } 2 m>x<5 m \text { (bukan aspal) kondisi tidak } \\
\text { berlubang } \\
\text { - Jalan lingkungsn: } 2 m>x<3 m \text { (aspal) kondisi tidak berlubang }\end{array}$ & 3 & & \\
\hline $\begin{array}{l}\text { - Jalan Arteri dengan lebar Primer = } 8 \text { meter dan kondisi baik (aspal) } \\
\text { - Jalan Kolektor dengan lebar }=7 \text { meter dan kondisi baik (aspal) } \\
\text { - Jalan lokal: lebar jalan } 2 m>x<5 \text { m (aspal) kondisi tidak berlubang } \\
\text { - Jalan lingkungan: } 3 m>x<4 m \text { (aspal) kondisi tidak berlubang }\end{array}$ & 4 & & \\
\hline $\begin{array}{l}\text { - Jalan Arteri Primer }>8 \text { meter dan kondisi baik (aspal) } \\
\text { - Jalan Kolektor dengan lebar }>7 \text { meter dan kondisi baik (aspal) } \\
\text { - Jalan lokal: lebar jalan >5 m (aspal) kondisi tidak berlubang } \\
\text { - Jalan lingkungsn: = 4m (aspal) kondisi tidak berlubang }\end{array}$ & 5 & & \\
\hline
\end{tabular}




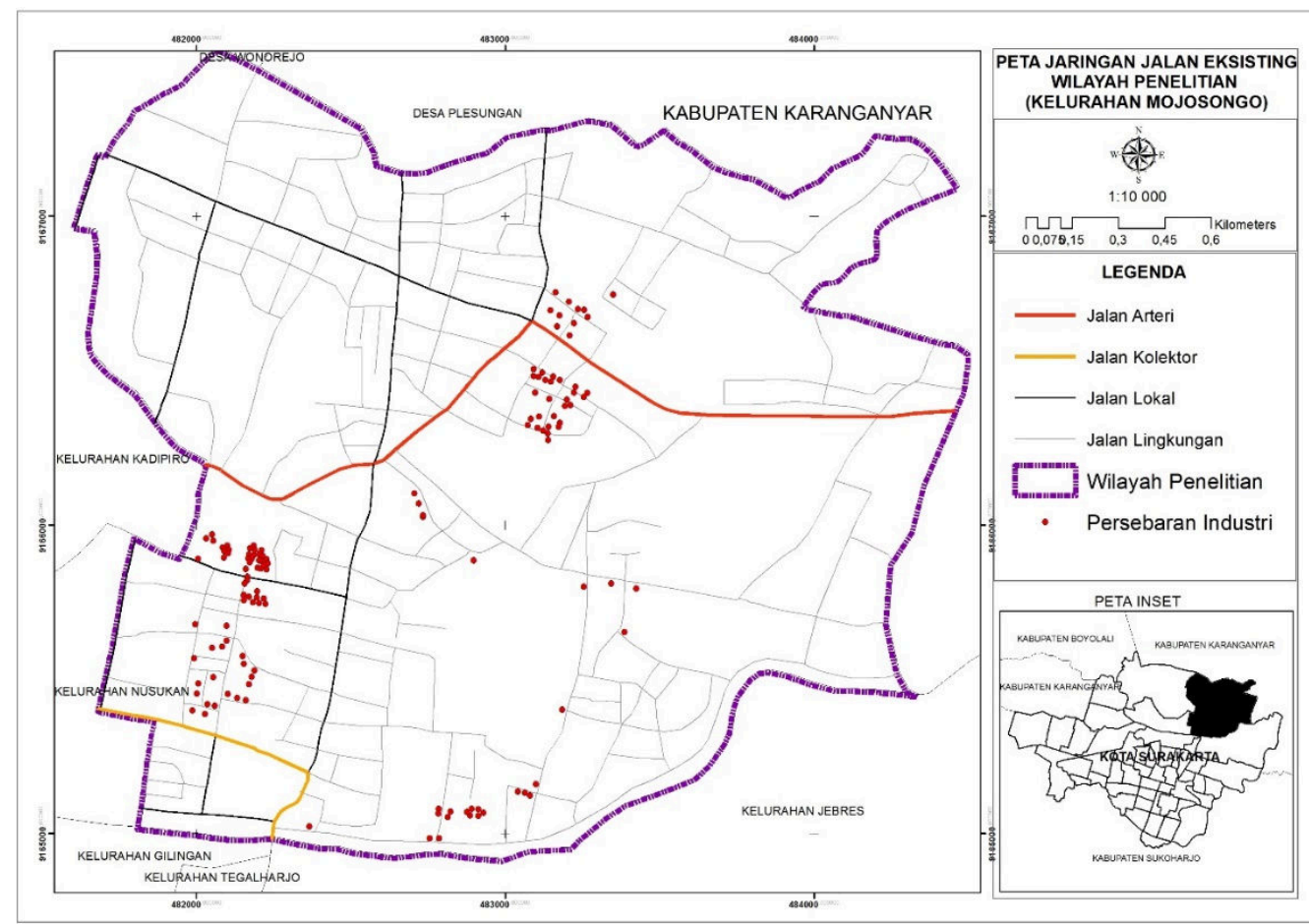

Sumber: Peneliti, 2017

Gambar 3. Peta Jaringan Jalan di Kelurahan Mojosongo

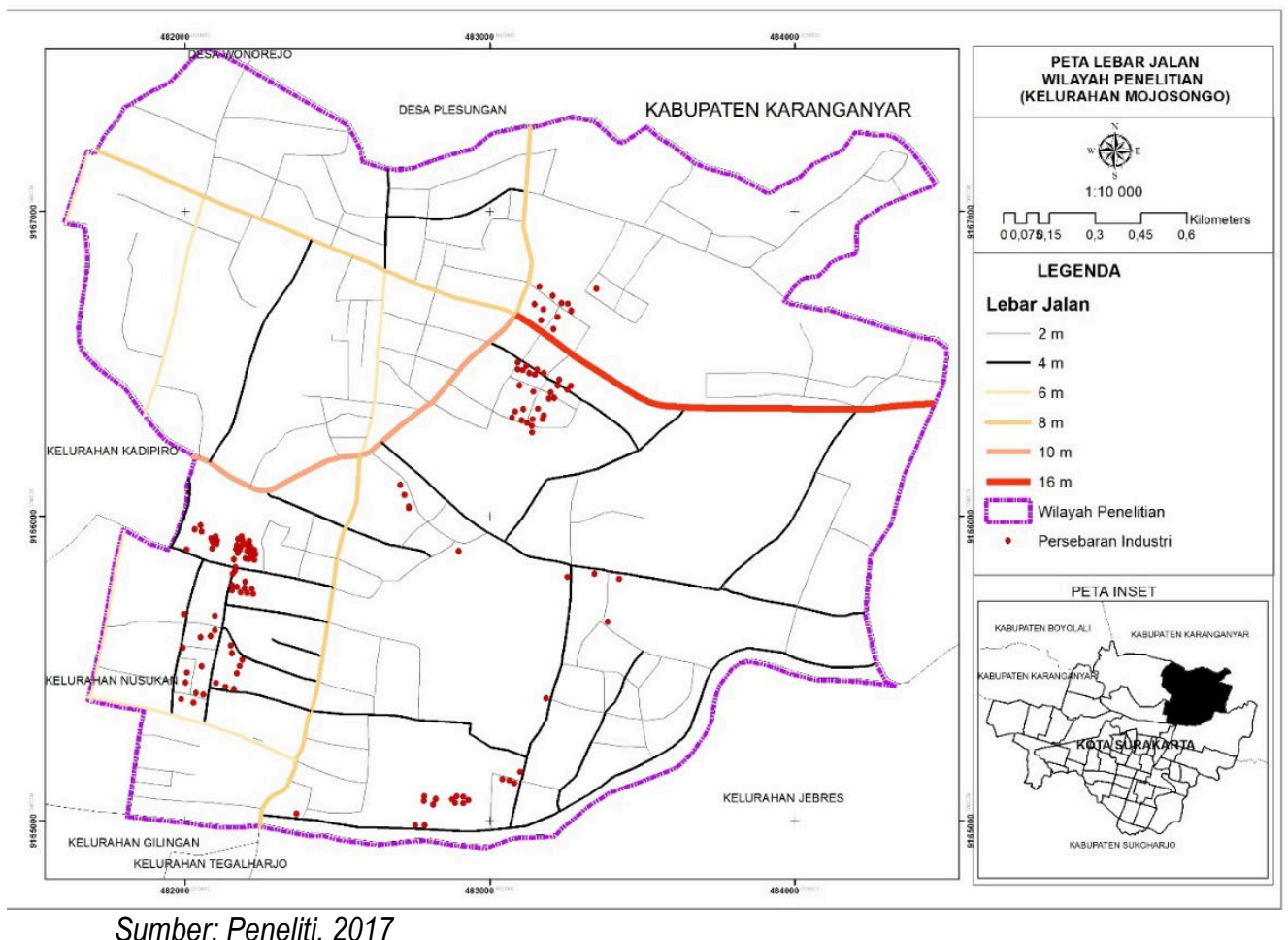

Gambar 4. Peta Lebar Jalan di Kelurahan Mojosongo

Pada wilayah penelitian kondisi dari jaringan jalan sudah tergolong kedalam kategori yang sangat baik, karena perkerasan jalan pada wilayah penelitian sudah menggunakan perkerasan aspal dengan kondisi rata-rata baik walaupun masih terdapat satu ruas jalan dengan kondisi jalan yang bergelombang yaitu pada jalan asteri primer pada wilayah penelitian, namun hal tersebut wajar karena jalan sering dialui oleh moda angkutan berat seperti truk, bus, dan moda angkutan berat lainnya. Selanjutnya, lebar jalan sudah sesuai dengan lebar dari jenis jalan yang seharusnya yaitu berdasarkan Keputusan Menteri Permukiman dan 
Prasarana Wilayah No. 534/Kpts/M/2001 dan SNI 03-6967-2003. Dapat dikatakan bahwa kesiapan dari akses jaringan jalan pada wilayah penelitian masuk kedalam kategori tingkat kesiapan sangat tinggi (sangat siap). Hal tersebut dapat menjadi potensi kawasan jika dikembangkan sebagai kawasan pariwisata berbasis industri kerajinan sangkar burung, karena kondisi akses jaringan jalannya baik dan dapat memudahkan mobilisasi wisatawan pada wilayah penelitian.

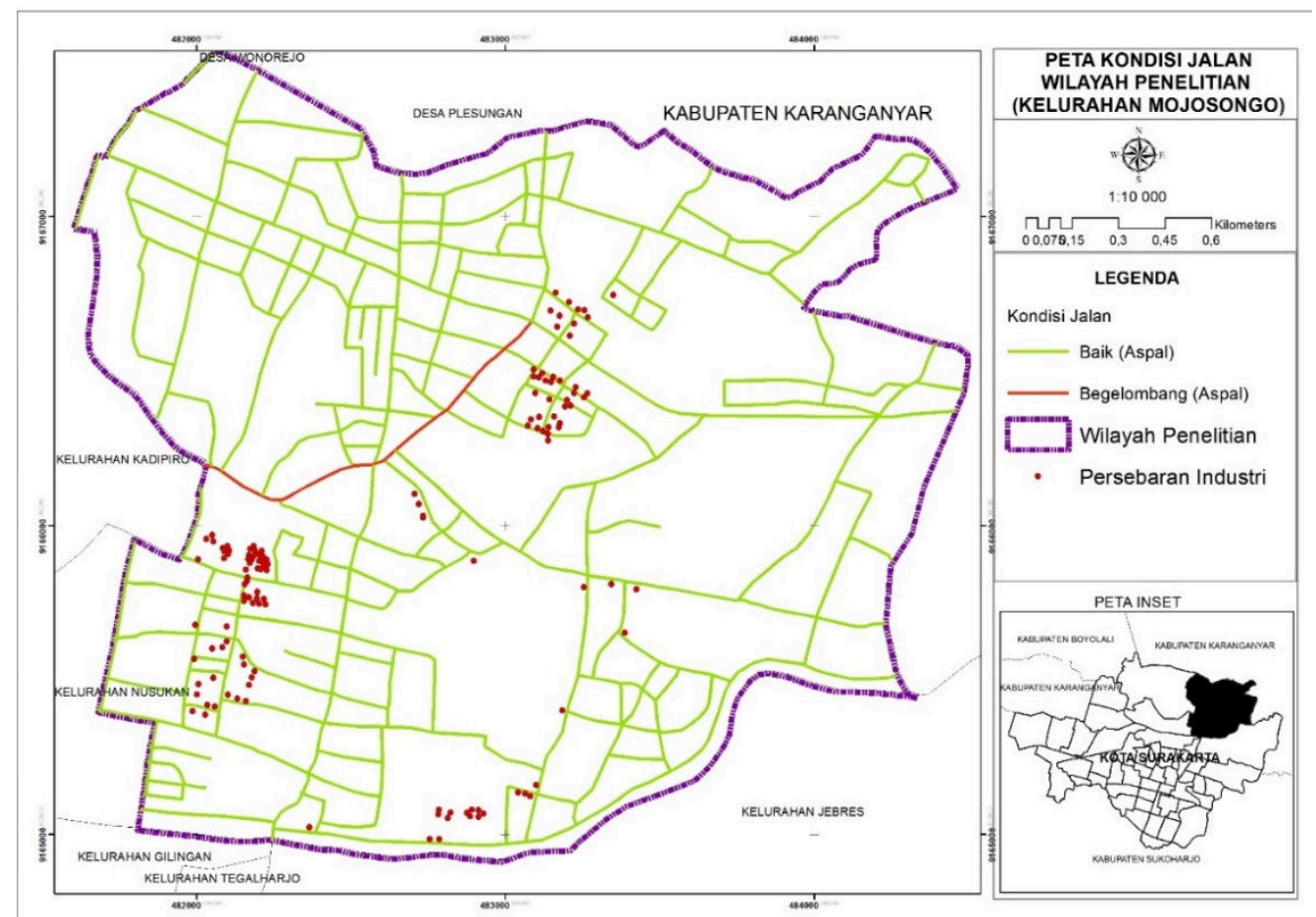

Sumber: Peneliti, 2017

Gambar 5. Peta Kondisi Jalan di Kelurahan Mojosongo

oKetersediaan rute moda transportasi umum

Ketersediaan rute moda transportasi umum pada kawasan pariwisata sangat berpengaruh terhadap aksesibilitas kawasan, karena dapat memudahkan wisatawan untuk dapat menuju atau mengakses destinasi wisata yang dituju (Gunn \& Turgut, 2002). Pada wilayah penelitian terdapat rute moda angkutan umum berupa angkot sebanyak dua rute). Instrument survei yang digunakan untuk mengukur indikator pada parameter ini yaitu menggunakan observasi lapangan dan survei data sekunder. Berdasarkan hasil survei, pada kawasan penelitian, terdpat 2 (dua) jalur (koridor) angkutan umum yang melintas melaui kawasan yaitu, koridor 8 (delapan) dan koridor 9 (sembilan). Jenis angkutan umum yang melewati kawasan penelitian adalah jenis moda angkutan kota (Angkot). Agar dapat mengakses koridor 8 dan 9 pada moda angkot yang melintasi kawasan, sebelumnya pengunjung harus menggunakan bus kota (BST). Selain itu, setelah pengunjung turun di kawasan penelitian, untuk mencapai kawasan industri kerajinan sangkar burung dapat ditempuh dengan berjalan kaki dengan jarak $\leq 800 \mathrm{~m}$. Seharusnya pemerintah dapat mengadakan rute moda transportasi berupa bus yang melalui wilayah penelitian, sehingga dapat lebih meningkatkan aksesibilitas kawasan bagi pengunjung yang datang. Dengan demikian dapat disimpulkan bahwa kesiapan pada rute moda angkutan umum masuk kedalam kategori tingkat kesiapan sedang (agak siap). 


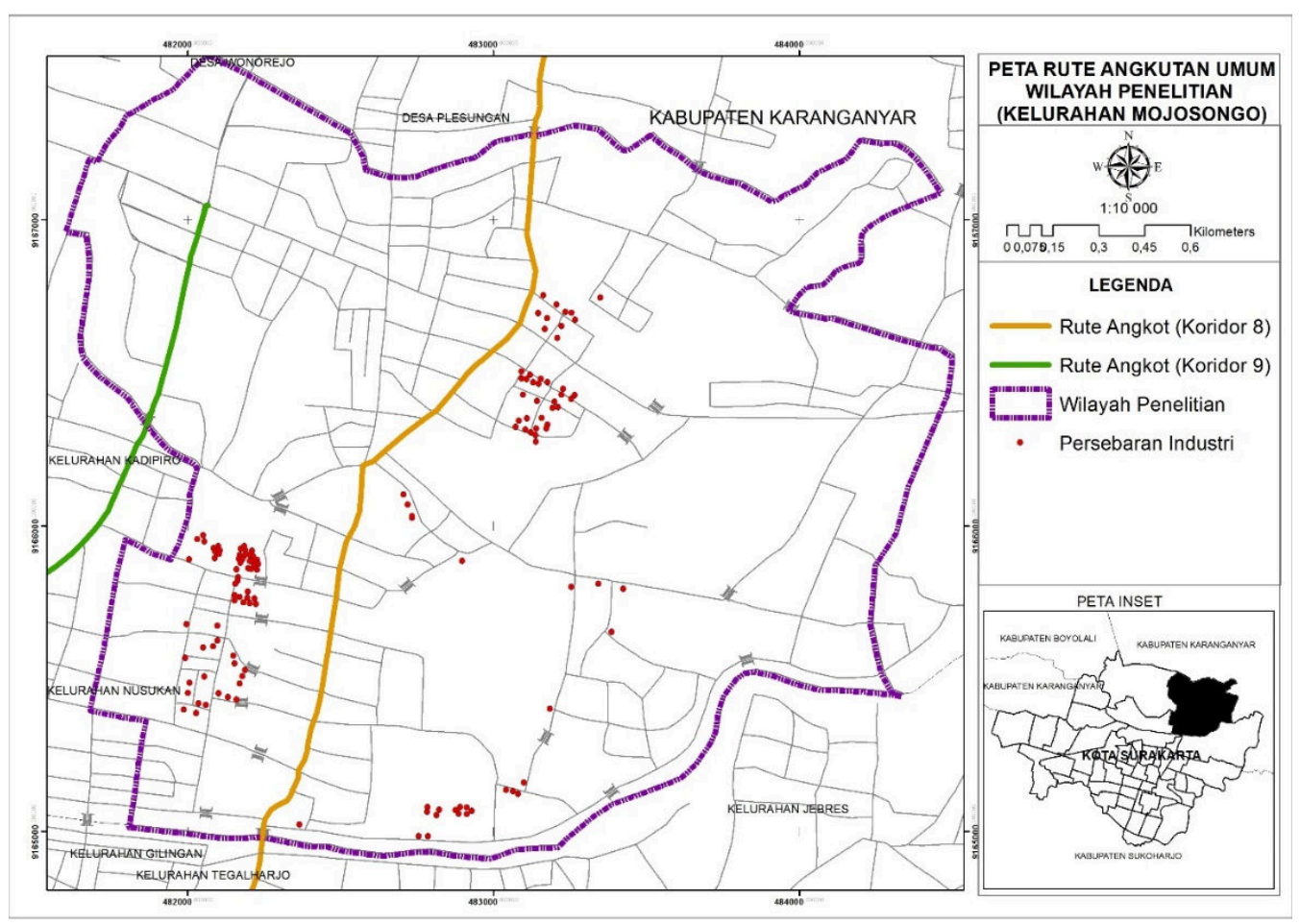

Sumber: Peneliti, 2017

Gambar 6. Peta Rute Moda Angkutan Umum di Kelurahan Mojosongo

\section{- Ketersediaan lahan}

Variabel ketersediaan lahan akan diukur dengan 2 (dua) parameter yaitu: (1) Ketersediaan lahan dilihat dari ada atau tidaknya arahan RDTRK Surakarta tahun 2011-2013 terkait penggunaan lahan yang dapat dijadikan pengembangan infrastruktur kawasan pariwisata berbasis industri kerajinan sangkar burung; dan (2) Ketersediaan lahan dilihat dari perbandingan luasan antara kebutuhan ruang untuk pengembangan infrastruktur kawasan dengan ketersediaan lahan pada kawasan yang ada pada arahan RDTRK Surakarta tahun 2011-2013. Berdasarkan data hasil survey observasi lapangan bahwa terdapat 125 (seratus duapuluh lima) titik industri kerajinan sangkar burung di wilayah penelitian (Kelurahan Mojosongo) yang tersebar di beberapa RW yaitu di RW 2, RW 3, RW 4, RW 7, RW 9, RW 11, dan RW 34. Selanjutnya, berdasarkan hasil kuisioner menunjukkan bahwa 96,43\% mengatakan bahwa showroom dibutuhkan pada wilayah penelitian jika dikembangkan sebagai kawasan pariwisata. Selanjutnya, sebanyak $60,71 \%$ dari responden mengatakan bahwa sarana persampahan dibutuhkan jika kawasan dikembangkan sebagai kawasan pariwisata. Sedangkan, infrastruktur lainnya hanya memiliki persentase sangat kecil yaitu sarana peribadatan (5,36\%), sarana penginapan (3,57\%), dan WC/Toilet Umum (3,57\%). Jadi, dapat disimpulkan yang memiliki total persentase yang terbesar merupakan infrastruktur yang dibutuhkan pada kawasan, jika suatu saat akan dikembangkan sebagai kawasan pariwisata berbasis industri kerajinan sangkar burung. Infrastruktur itu adalah Showroom dan Sarana Persampahan. Selanjutnya, berikut merupakan data hasil survey data sekunder yaitu melihat ketersediaan lahan dilihat dari arahan pola ruang pada RDTR Kota Surakarta tahun 2011-2031 dan peruntukan lahan eksisting pada wilayah penelitian. Dari hasil survey tersebut didapatkan data sebagai berikut.

Tabel 8. Perbandingan Antara Luasan Arahan Peruntukan Lahan RDTR Kota Surakarta tahun 2011-2031 dengan Peruntukan Lahan Eksisting pada Wilayah Penelitian

\begin{tabular}{|c|c|l|l|c|}
\hline $\begin{array}{c}\text { Arahan Peruntukan Lahan RDTR Kota } \\
\text { Surakarta tahun } \\
\text { Wilayah Penelitian }\end{array}$ & \multicolumn{2}{|c|}{$\begin{array}{c}\text { Peruntukan Lahan Eksisting pada } \\
\text { Wilayah Penelitian }\end{array}$} & \multirow{2}{*}{$\begin{array}{c}\text { Selisih } \\
\left(\mathbf{m}^{2}\right)\end{array}$} \\
\hline Peruntukan Lahan & Luas $\left(\mathbf{m}^{2}\right)$ & \multicolumn{1}{|c|}{$\begin{array}{c}\text { Peruntukan } \\
\text { Lahan }\end{array}$} & Luas $\left(\mathbf{m}^{2}\right)$ & \\
\hline $\begin{array}{c}\text { Pengolahan } \\
\text { Sampah }\end{array}$ & $4.159,933$ & $\begin{array}{l}\text { Pengolahan } \\
\text { Sampah }\end{array}$ & $2.730,452$ & $1.429,48$ \\
\hline Perdagangan Jasa & $143.121,1$ & Perdagangan & 139.497 & $3.624,08$ \\
\hline
\end{tabular}




\begin{tabular}{|c|c|c|c|c|}
\hline $\begin{array}{c}\text { Arahan Peruntukan Lahan RDTR Kota } \\
\text { Surakarta tahun 2011-2031 pada } \\
\text { Wilayah Penelitian }\end{array}$ & $\begin{array}{c}\text { Peruntukan Lahan Eksisting pada } \\
\text { Wilayah Penelitian }\end{array}$ & \multirow{2}{*}{$\begin{array}{c}\text { Selisih } \\
\left(\mathrm{m}^{2}\right)\end{array}$} \\
\hline Peruntukan Lahan & Luas $\left(\mathrm{m}^{2}\right)$ & $\begin{array}{c}\text { Peruntukan } \\
\text { Lahan }\end{array}$ & Luas $\left(\mathrm{m}^{2}\right)$ & \\
\hline & Jasa & & \\
\hline
\end{tabular}

Berdasarkan hal di atas dapat dihitung perbandingan antara kebutuhan lahan dari sarana showroom dan prasarana persampahan (berupa bak berukuran $10 \mathrm{~m}^{2}$ / RW yang terdapat industri sangkar burung). Berikut merupakan tabel hasil analisis variabel ketersediaan lahan pada wilayah penelitian.

Tabel 9. Analisis Ketersediaan Lahan pada Wilayah Penelitian

\begin{tabular}{|l|l|l|c|c|}
\hline Jenis Sarana & \multicolumn{1}{|c|}{ Kebutuhan Lahan (DLi) } & \multicolumn{1}{|c|}{ Lahan yang Tersedia (SLi) } & $\begin{array}{c}\text { Ketersediaan } \\
\text { lahan (DDi) }\end{array}$ & Skor \\
\hline Showroom & $\begin{array}{l}\text { Jumlah titik industri kerajinan } \\
\text { sangkar burung }=125 \text { titik, } \\
\text { dikalikan dengan satandar } \\
\text { luasan showroom }=100 \mathrm{~m}^{2}= \\
12500 \mathrm{~m}^{2}\end{array}$ & $\begin{array}{l}\text { Showroom dapat dikatagorikan sebagai } \\
\text { peruntukan lahan perdagangan dan jasa } \\
\text { maka dari itu lahan yang tersedia } \\
\text { berdasarkan arahan RDTR Kota } \\
\text { Surakarta dikurang dengan peruntukan } \\
\text { lahan eksistingnya pada wilayah } \\
\text { penelitian yaitu seluas 3624,08 } \mathrm{m}^{2}\end{array}$ & DDi $=0,3$ & 2 \\
\hline $\begin{array}{l}\text { Sarana } \\
\text { Persampahan }\end{array}$ & $\begin{array}{l}\text { Jumlah RW yang terdapat } \\
\text { industri kerajinan sangkar } \\
\text { burung = } 7 \text { RW, di kalikan } \\
\text { dengan standar ukuran bak } \\
\text { sampah setiap RW }=10 \mathrm{~m}^{2}= \\
70 \mathrm{~m}^{2}\end{array}$ & $\begin{array}{l}\text { Sarana bak sampah setiap RW dapat } \\
\text { dikatagorikan sebagai peruntukan lahan } \\
\text { pengelolaan sampah pada arahan RDTR } \\
\text { Kota Surakarta yang dikurangi dengan } \\
\text { luasan eksistingnya pada wilayah } \\
\text { penelitian yaitu seluas } 1429,48 \mathrm{~m}^{2}\end{array}$ & DDi $=20,4$ & 5 \\
\hline
\end{tabular}

Sumber: Analisis Peneliti, 2017

Ketersediaan lahan untuk sarana showroom pada wilayah penelitian dapat dikatakan rendah karena nilai DDi (keterediaan lahan) adalah 0,3 yang seharusnya bernilai 1 (kebutuhan lahan dan supply lahannya sama luas). Selanjutnya, untuk ketersediaan untuk pengembangan prasarana persampahan dapat dikatakan memiliki ketersediaan lahan yang sangat tinggi, karena memiliki DDi (ketersediaan lahan) adalah 20,4 (Muta'ali, 2015). Hal itu menunjukkan ketersediaan lahan untuk prasarana persampahan masih banyak tersedia pada wilayah penelitian. Dengan demikian dapat disimpulkan bahwa tingkat kesiapan pada wilayah penelitian masuk kedalam kategori tingkat kesiapan sedang (agak siap). Hal tersebut karena masih perlu adanya penambahan peruntukan lahan untuk sarana showroom dengan menambah luasan lahan yang diperuntukkan sebagai perdagangan dan jasa pada arahan pola ruang kawasan. Hal tersebut tentunya hanya dapat dilakukan oleh pihak yang memiliki wewenang dalam pembuatan kebijakan terkait peraturan peruntukan lahan pada kawasan yaitu pemerintah.

Berdasarkan kesiapan setiap variabel yang telah dibahas di atas, maka kesiapan pengembangan kawasan didapat dari akumulasi skor dari masing-masing komponen pengembangan kawasan yang dikalikan dengan bobotnya. Berikut merupakan sintesa kesiapan pengembangan kawasan pada wilayah penelitian.

Tabel 10. Hasil Skoring Kesiapan Aspek Spasial pada Pengembangan Kawasan

\begin{tabular}{|c|c|c|c|c|c|c|c|c|c|}
\hline \multirow[b]{2}{*}{ Variabel } & \multirow{2}{*}{$\begin{array}{c}\text { Sub } \\
\text { Variabel }\end{array}$} & \multirow[b]{2}{*}{$\begin{array}{l}\text { Rata-Rata } \\
\text { Skor Varibel }\end{array}$} & \multicolumn{5}{|c|}{ Tingkat Kesiapan } & \multirow[b]{2}{*}{$\begin{array}{c}\text { Bobot } \\
(\%)\end{array}$} & \multirow{2}{*}{$\begin{array}{l}\text { Skor } \\
\text { variabel } x \\
\text { Bobotnya }\end{array}$} \\
\hline & & & $\begin{array}{c}\text { Sangat } \\
\text { tidak siap }\end{array}$ & $\begin{array}{l}\text { Tidak } \\
\text { siap }\end{array}$ & $\begin{array}{c}\text { Agak } \\
\text { siap }\end{array}$ & Siap & $\begin{array}{c}\text { Sangat } \\
\text { siap }\end{array}$ & & \\
\hline $\begin{array}{l}\text { Lingkungan } \\
\text { kreatif }\end{array}$ & - & 5,00 & & & & & $\mathrm{v}$ & $27,77 \%$ & 1,39 \\
\hline \multirow{2}{*}{ Infrastruktur } & Sarana & \multirow{2}{*}{2,42} & $\mathrm{v}$ & & & & & \multirow{2}{*}{$25,71 \%$} & \multirow{2}{*}{0,62} \\
\hline & Prasarana & & & & & $\mathrm{v}$ & & & \\
\hline Aksesibilitas & - & 4,00 & & & & $\mathrm{~V}$ & & $25,13 \%$ & 1,01 \\
\hline $\begin{array}{l}\text { Ketersediaan } \\
\text { Lahan }\end{array}$ & - & 3,50 & & & & v & & $21,39 \%$ & 0,75 \\
\hline
\end{tabular}




\begin{tabular}{|c|c|c|c|c|c|c|c|c|c|}
\hline \multirow[b]{2}{*}{ Variabel } & \multirow{2}{*}{$\begin{array}{c}\text { Sub } \\
\text { Variabel }\end{array}$} & \multirow[b]{2}{*}{$\begin{array}{c}\text { Rata-Rata } \\
\text { Skor Varibel }\end{array}$} & \multicolumn{5}{|c|}{ Tingkat Kesiapan } & \multirow[b]{2}{*}{$\begin{array}{c}\text { Bobot } \\
(\%)\end{array}$} & \multirow{2}{*}{$\begin{array}{l}\text { Skor } \\
\text { variabel } x \\
\text { Bobotnya }\end{array}$} \\
\hline & & & $\begin{array}{c}\text { Sangat } \\
\text { tidak siap }\end{array}$ & $\begin{array}{l}\text { Tidak } \\
\text { siap }\end{array}$ & $\begin{array}{l}\text { Agak } \\
\text { siap }\end{array}$ & Siap & $\begin{array}{l}\text { Sangat } \\
\text { siap }\end{array}$ & & \\
\hline $\begin{array}{l}\text { Lingkungan } \\
\text { kreatif }\end{array}$ & - & 5,00 & & & & & $\mathrm{v}$ & $27,77 \%$ & 1,39 \\
\hline \multicolumn{3}{|c|}{$\begin{array}{l}\text { Tingkat Kesiapan Pengembangan } \\
\text { Kawasan }\end{array}$} & \multicolumn{6}{|c|}{ Siap } & 3,77 \\
\hline
\end{tabular}

Sumber: Analisis Peneliti, 2017

Dari kategori di atas, skor kesiapan $(3,77)$ berdasarkan hasil analisis pada artikel ini berada pada katagori siap atau dapat dikatakan sebagai kawasan yang memiliki kesiapan aspek spasial yang tinggi jika dikembangkan sebagai kawasan pariwisata berbasis industri rumah tangga kreatif kerajinan sangkar burung.

\section{KESIMPULAN}

Kelurahan Mojosongo berpotensi dan diarahkan sebagai kawasan pengembangan pariwisata berbasis industri kerajinan sangkar burung. Dalam pengembangan kawasan tentunya harus memperhatikan kesiapan kawasanya. Artikel ini membahas terkait kesiapan pengembangan kawasan pada aspek spasial (fisik ruang). Pola persebaran industri pada wilayah penelitian memiliki pola persebaran mengelompok (klaster), hal tersebut sangat berpeluang untuk diwijudkan sebagai lingkungan kreatif industri kerajinan sangkar burung. Selain itu, kawasan akan mudah untuk dikelola karena dengan pola persebaran mengelompok (klater) akan memiliki efisiensi dan efektifitas secara spasial. Selanjutnya, prasarana penunjang pada kawasan sudah cukup memadai mulai dari pasarana persampahan, prasarana air bersih, prasarana listrik, dan prasarana telekomunikasi. Namun, untuk sarana penunjang kawasan berupa showroom, masih belum tersedia pada kawasan. Seharusnya, pemerintah dapat bekerja sama dengan masyarakat pelaku usaha untuk mengadakan sarana showroom tersebut. Jika dilihat dari ketersediaan lahannya, pada wilayah penelitian, sudah tersedia lahan untuk pengembangan sarana showroom, namun secara luasan masih agak kurang. Ketersediaan lahan untuk pengembangan prasarana persampahan berupa bak setiap RW sudah tersedia dan secara luasan sudah mencukupi. Berikutnya, aksesibilitas pada kawasan sudah baik, karena kondisi dan kapasitas dari akses jaringan jalan ada wilayah penelitian sudah memenuhi standar. Selain itu, ketersediaan rute moda agkutan umum yang melalui kawasan sudah tersedia, namun jenis moda trasportasi umum yang melalui wilayah penelitian berupa angkot. Perlu penambahan terkait jalur rute angkutan umum berupa bus di Kota Surakarta, agar dapat melintasi wilayah penelitian, sehingga dapat meningkatkan aksesibilitas kawasan jika dikembangkan sebagai kawasan pariwisata berbasis industri kerajinan sangkar burung. Jadi, dapat disimpulkan kesiapan kawasan pada aspek spasial pada wilayah penelitian secara keseluruhan masuk kedalam kategori tingkat kesiapan tinggi (Siap).

Berdasarkan kesimpulan yang telah dijabarkan sebelumnya, maka rekomendasi yang diajukan kepada pemerintah dan penelitian selanjutnya adalah sebagai berikut.

1. Untuk pemerintah setempat:

- Instansi terkait pengembangan kawasan perlu bekerja sama dengan kelompok masyarakat maupun kelembagaan swasta terkait pengadaan sarana showroom untuk memamerkan dan menjual produk kerajinan sangkar burung bagi pelaku usaha pada wilayah penelitian.

- Penyediaan lahan untuk sarana dan prasarana dalam pengemangan kawasan perlu diperhatikan oleh stakeholder terkait.

- Dinas Pariwisata, BAPPPEDA, dan Dinas Perhubungan Kota Surakarta seharusnya bekerjasama terkait pengitegrasian wilayah penelitian dengan objek-objek wisata di Kota Surakarta melalui pengadaan paket wisata dan pengembangan rute moda angkutan uum berupa bus yang melaui wilayah penelitian.

2. Untuk penelitian selanjutnya:

- Perlu penelitian yang lebih spesifik untuk membahas masing-masing komponen kesiapan aspek spasial pada pengembangan kawasan pariwisata berbasis industri kerajinan sangkar burung secara lebih mendalam dan mendetail.

- Penelitian ini belum membahas terkait aspek sosial secara spesifik, seperti partisipasi masyarakat, sosial budaya, dan komponen aspek sosial lainnya yang sekiranya dapat berpengaruh pada pengembangan kawasan kedepannya. 


\section{DAFTAR PUSTAKA}

\section{Buku}

Adisasmita, Rahardjo. 2010. Pembangunan Kawasan dan Tata Ruang. Yogyakarta: Graha Ilmu.

Adisasmita, Rahardjo. 2014. Ekonomi Tata Ruang Wilayah. Yogyakarta: Graha IImu.

Bintarto, R., Hadisumarno S. 1982. Metode Analisa Geografi. Jakarta: LP3ES.

Departemen Perdagangan RI. 2008. Pengembangan Ekonomi Kreatif Indonesia 2025: Rencana Pengembangan Ekonomi Kreatif Indonesia 2009 - 2015.

Gunn, Clare A with Turgut Var. 2002. Tourism Planning Basic, Concepts, Cases. New York: Routledge.

Hamalik. 2006. Proses Belajar Mengajar. Bandung: Bumi Aksara.

Muta'ali, Luthfi. 2015. Teknik Analisis Regional. Yogyakarta: Badan Penerbit Fakultas Geografi (BPFG) UGM.

Pendit, Nyoman S. 1999. IImu Pariwisata-Sebuah Pengantar Perdana. Jakarta: PT. Pradnya Paramita.

Slameto. 2010. Belajar dan Faktor-Faktor yang Mempengaruhinya. Jakarta: Rineka Cipta.

\section{Jurnal}

Adiati, Maria P dan Basalamah, A. 2014. Kondisi Pariwisata Berkelanjutan Di Bidang Sosial Budaya Berdasar Pengalaman Dan Harapan Pengunjung Di Pantai Tanjung Papuma, Jember. Jakarta Barat: Binus Business Review Vol. 5 No. 1.

Mawaddah, Alina Masda. 2013. Distribusi dan Karakteristik Industri Rumah Tangga Pangan di Kecamatan Ungaran Barat. Semarang: Skripsi Jurusan Geografi Fakultas Ilmu Sosial.

Munawir, H dkk. 2015. Analisis Supply Chain Management Industri Kerajinan Sangkar Burung Di Surakarta. Surakarta: Simposium Nasional Teknologi Terapan (SNTT) 3.

Redlener, Irwin, dkk. 2006. National Preperedness Planning: The Historical Context and Current State of The U.S. Public's Readiness, 1940-2005. The Trustees of Coloumbia University in te City of New York: Journal of International Affairs, Spring/Summer 2006, Vol. 59, No.2.

Richards, Greg. 2011. Creativity and Tourism The State of Arts. Netherlands: Annals of Tourism Reaseacrh Vol. 38 No. 4.

Saaty, T.L. 2008. Decision making with the analytic hierarchy process, Int. J.Services Sciences, Vol. 1, No. 1.

Suyatmi, Pujihartati, Sri Hilmi., Bambang. 2014. Seni, Budaya dan Industri Kreatif Masyarakat Pedesaan Untuk Pariwisata. Surakarta: Laporan Penelitian Hibah Unggulan Fakultas.

UNIDO. 2007. Creative Industries and Micro \& Small Scale Enterprise Development.

Zakaria, Faris, dkk. 2014. Konsep Pengembangan Kawasan Desa Wisata di Desa Bandungan Kecamatan Pakong Kabupaten Pamekasan. Institute Teknologi Bandung: Jurnal Teknik POMITS Vol.3, No.2.

\section{Dokumen Pemerintah}

Keputusan Menteri Permukiman Dan Prasarana Wilayah No. 534/Kpts/M/2001 tentang Pedoman Penentuan Standar Pelayanan Minimal Bidang Penataan Ruang, Perumahan Dan Permukiman Dan Pekerjaan Umum.

Peraturan Menteri Pekerjaan Umum RI No.03/PRT/M/2013 tentang Penyelenggaraan Sarana dan Prasarana Persampahan Rumah Tangga dan Sejenisnya.

Rencana Tata Ruang Wilayah Kota Surakarta tahun 2011-2031.

Rencana Detail Tata Ruang Kota Surakarta tahun 2011-2031.

SNI 03-1733-2004 tentang Tata Cara Perencanaan Lingkungan Perumahan Di Perkotaan.

SNI 03-6967-2003 tentang Persyaratan Umum Sistem Jaringan dan Geometrik Jalan Perumahan. 